\title{
Description of a Novel Monopartite Geminivirus and Its Defective Subviral Genome in Grapevine
}

\author{
Maher Al Rwahnih, Olufemi J. Alabi, Nathaniel M. Westrick, Deborah Golino, and Adib Rowhani
}

First, third, fourth, and fifth authors: Department of Plant Pathology, University of California, Davis, 95616; and second author: Department of Plant Pathology \& Microbiology, Texas A\&M AgriLife Research and Extension Center, Weslaco 78596. Accepted for publication 14 September 2016.

\begin{abstract}
A novel virus was detected in grapevines by Illumina sequencing during the screening of two table grape (Vitis vinifera) accessions, cultivars Black Beet and Nagano Purple, from South Korea. The monopartite circular ssDNA genome sequence was subsequently confirmed by rolling cycle amplification, cloning and Sanger sequencing. The complete viral genomic sequence from both accessions ranged from 2,903 to 2,907 nucleotides in length and contained the conserved nonanucleotide sequence TAATATT $\downarrow$ AC and other sequence features typical of the family Geminiviridae, including two predicted sense and four complementary-sense open reading frames. Phylogenetic analysis placed the novel virus in a unique taxon within the

family Geminiviridae. A naturally occurring defective subviral DNA was also discovered. This defective DNA molecule carried a deletion of approximately $46 \%$ of the full-length genome. Both the genomic and defective DNA molecules were graft-transmissible although no disease is yet correlated with their occurrence in Vitis spp. The tentative names Grapevine geminivirus A (GGVA) and GGVA defective DNA (GGVA D-DNA) are proposed. PCR assays developed using primers designed in the coat protein gene led to the detection of GGVA in $1.74 \%$ of 1,262 vines derived from 15 grapevine cultivars from six countries across three continents.
\end{abstract}

Grapes (Vitis spp.) are one of the world's most ancient fruit crops. They are sold fresh as table grapes or used to produce wine, raisins, jelly, juice, and other grape products thus generating significant economic activity worldwide. In the United States, California is by far the leading producer of grapes and grape products, accounting for $90 \%$ of the bottled wines (http://www.wineinstitute.org) and almost $100 \%$ of table grapes and raisins produced in the country (http://www.grapesfromcalifornia.com/). Due to the continued recognition of the threat of viruses to the sustainability of the grapevine industry, considerable investments are being made to improve the capacity to accurately and rapidly identify and characterize potentially economically damaging viruses. Additionally, efforts are made to control their impact before they become widespread and high-throughput sequencing (HTS) technology has the potential to enhance these control efforts. The comprehensive nature of HTS analysis, its analytical speed, and improved sensitivity over traditional methods improve surveys of recognized viruses and the discovery of novel viruses (Al Rwahnih et al. 2015).

With over 70 infectious agents identified and characterized across the globe, grapevine has the distinction of being host to the highest number of intracellular pathogens of any crop (Martelli 2014). Most of these infectious agents are viruses with ribonucleic acid (RNA) genomes (Maliogka et al. 2015a; Martelli 2014). However, three viruses with deoxyribonucleic acid (DNA) genomes have also been documented from grapevines within the last decade. This further complicates the already complex virome in the vineyard. The grapevine-infecting DNA viruses are Grapevine vein clearing virus (GVCV; genus Badnavirus; family Caulimoviridae)

Corresponding authors: A. Rowhani; E-mail address: akrowhani@ucdavis.edu, and M. Al Rwahnih; E-mail address: malrwahnih@ucdavis.edu

*The $\boldsymbol{e}$-Xtra logo stands for "electronic extra" and indicates that two supplementary figures are published online.

(c) 2017 The American Phytopathological Society
(Zhang et al. 2011), Grapevine red blotch-associated virus (GRBaV; family Geminiviridae) (Al Rwahnih et al. 2012a; Krenz et al. 2012; Poojari et al. 2013), and grapevine Roditis leaf discolorationassociated virus (GRLDaV; genus Badnavirus) (Maliogka et al. 2015b). GRBaV has been shown to be widespread in multiple cultivars across several grapevine-growing states of the Unites States (Al Rwahnih et al. 2013; Krenz et al. 2014) and is linked to reduced productivity of affected vines (Sudarshana et al. 2015) akin to the negative impacts reported for grapevine leafroll disease (Alabi et al. 2016a). Due to the recognition of the increasing importance of members of the family Geminiviridae as serious threats to global agriculture (Briddon 2015), the discovery of GRBaV has generated tremendous interest in DNA viruses within the global community of grapevine virologists.

The viruses belonging to the family Geminiviridae are characterized by their circular, single-stranded DNA (ssDNA) genomes encapsidated in geminate (twinned) incomplete icosahedral particles (Brown et al. 2012). Monopartite geminiviruses possess a single copy of the ssDNA genome (resembling the DNA-A component of begomoviruses) that typically encodes two virion-sense (V1 and V2) and two to four complementary-sense (C1 to C4) genes. Geminiviruses with bipartite genomes possess two ssDNA genome components (DNA-A and DNA-B components). The DNA-B component encodes one gene each in the virion- (BV1) and complementary-sense (BC1) orientations. Although some of the most recently discovered geminivirus-like sequences, particularly those characterized from perennial host plants, have relatively bigger genomes, each genome component ranges in size from 2.5 to $3.0 \mathrm{~kb}$ (Brown et al. 2012). To date, seven genera that differ considerably in their genome organization and biological properties have been recognized in the family Geminiviridae (Varsani et al. 2014). A unique commonality across species within the different genera in the family is the presence of a conserved nonanucleotide sequence motif "TAATATT $\downarrow$ AC" at the origin of virion-strand replication within the intergenic region (Brown et al. 2012). The only exceptions are members of the genus Becurtovirus and Eragrostis curvula streak virus which have two nucleotide 
substitutions at positions four ( $\mathrm{T}$ to $\mathrm{G}$ ) and eight (A to $\mathrm{C}$ ) of their nonanucleotide sequence motifs.

In addition to their monopartite or bipartite ssDNA genome components, some geminiviruses may have additional subgenomic defective DNA (Stenger et al. 1992) and/or satellite DNA (Briddon et al. 2003; Saunders and Stanley 1999; Zhou 2013). These are ssDNA molecules that are typically half the size of the genomic component and may be associated with symptom modulation in the host plant (Patil and Dasgupta 2006). The defective molecules may be derived from either of the two genomic components or even from the satellite DNA molecule. Typically, the defective molecules derived from the DNA-A component contain the intergenic region with all the cis-acting sequences required for replication (including the "TAATATT $\downarrow$ AC" nonanucleotide sequence motif), the Nterminal sequences of the Rep-associated protein and sometimes a small part of gene encoding coat protein (CP) (Patil and Dasgupta 2006). Those derived from the DNA-B component, on the other hand, typically contain part of the $\mathrm{BC} 1$ protein but lack the BV1 gene (Patil and Dasgupta 2006). Studies have shown that the defective molecules can be encapsidated by the geminivirus $\mathrm{CP}$ to form isometric particles (Bottcher et al. 2004; Casado et al. 2004; Frischmuth et al. 2001) thus enabling their transmission by the insect vector (Czosnek et al. 1989). Defective nucleic acid (RNA or DNA) molecules may or may not interfere with the replication of their parental (helper) virus genomic component (Patil and Dasgupta 2006; Simon et al. 2004). Those that impair the replication of the helper virus are referred to as defective interfering (DI-DNA) molecules while those that do not (or whose biological functions are yet to be determined) are simply called defective (D-DNA) molecules. To date, no D-DNA or DI-DNA molecule has been characterized from grapevines to the best of our knowledge.

In the present study, we report the natural occurrence and discovery of a novel ssDNA virus, tentatively named Grapevine geminivirus A (GGVA), and of a putative defective DNA molecule (GGVA D-DNA) associated with the virus in one of two isolates. This is the first evidence for the natural occurrence of a D-DNA molecule in grapevines. Both the viral genomic and defective DNA molecules are graft, but not mechanically, transmissible.

\section{MATERIALS AND METHODS}

Plant material. In 2013, two accessions of table grapes (Vitis vinifera), cultivars Black Beet (BB) and Nagano Purple (NP), were received as dormant cuttings from South Korea under a USDAAPHIS-PPQ588 controlled import permit for inclusion in the Foundation Plant Services (FPS, UC-Davis, CA) Public Collection. Representative canes of each accession were propagated on their own root as two node cuttings under mist and maintained in FPS quarantine growing facilities. Four plants of each cultivar were maintained within an insect-proof greenhouse enclosure. The plants were observed for virus-like symptoms for 2 to 3 months after bud break and leaf tissue (with petioles intact) was sampled for virus detection.

Assays for known grapevine pathogens. Total nucleic acid (TNA) extracts were prepared from the NP and BB source vines as described by Al Rwahnih et al. (2012b). Briefly, approximately $0.2 \mathrm{~g}$ of leaf petioles was homogenized using a HOMEX grinder (ThermoFisher Scientific, Grand Island, NY) and TNA extracts were prepared using a MagMAX-96 viral RNA isolation kit (ThermoFisher Scientific) as per manufacturer's protocol. Extracted TNA samples were analyzed by reverse transcription quantitative PCR (RT-qPCR) using TaqMan probes on the QuantStudio 6 Flex Real-Time PCR System (ThermoFisher Scientific) as described previously (Osman et al. 2008; Klaassen et al. 2011). The samples were screened for the following pathogens: Grapevine leafroll-associated virus-1 (GLRaV-1), Grapevine leafroll-associated virus-3 (GLRaV-3), and Grapevine leafroll-associated virus-4
(GLRaV-4, plus strains 9 and Car) (genus Ampelovirus); Grapevine leafroll-associated virus-2 (GLRaV-2, plus strain 2RG; genus Closterovirus); Grapevine leafroll-associated virus-7 (GLRaV-7; genus Velarivirus); Grapevine fleck virus (GFkV; genus Maculavirus); Grapevine rupestris vein feathering virus (GRVFV; genus Marafivirus); Grapevine fanleaf virus (GFLV), Tobacco ringspot virus (TRSV), and Tomato ringspot virus (ToRSV) (genus Nepovirus); Grapevine virus A (GVA), Grapevine virus B (GVB), Grapevine virus D (GVD), and Grapevine virus E (GVE) (genus Vitivirus); Grapevine rupestris stem-pitting associated virus (GRSPaV; genus Foveavirus); phytoplasmas and Xylella fastidiosa, the causative agent of Pierce's disease. The vines were also screened for the recently described Grapevine fabavirus (GFabV) (Al Rwahnih et al. 2016).

Biological assays. Since symptoms atypical of currently known grapevine viruses were observed only on vines of cultivar NP(Fig. 1A), assays were conducted to determine if the putative etiological agent(s) associated with the observed symptoms is graft- and/or mechanically transmissible. Bud chips from symptomatic NP vines and asymptomatic BB vines were grafted onto Cabernet franc (V. vinifera) test plants as described in Al Rwahnih et al. (2015). In addition, leaf petiole tissue from NP and BB vines was mechanically inoculated onto a panel of herbaceous indicator plants including Chenopodium amaranticolor, Chenopodium quinoa, Cucumis sativus, and Nicotiana clevelandii as previously described (Rowhani et al. 2005).

HTS and sequence analysis. Aliquots of TNA samples from the NP and BB source plants were subjected to ribosomal RNA (rRNA) depletion and cDNA library construction using a TruSeq Stranded Total RNA with Ribo-Zero Plant kit (Illumina). Sequencing was performed on the Illumina NextSeq 500 platform at the SeqMatic LLC sequencing facility (Fremont, CA) and the raw HTS reads were trimmed using the CLC Bio Genomic Workstation (Qiagen, Hilden, Germany) trimming tool. Contiguous consensus sequences "contigs" were then assembled from the non-Vitis reads using the CLC assembler (200 bp minimum). The NCBI blastx program (https://blast.ncbi.nlm.nih.gov/Blast.cgi) was used to compare contigs to reference virus genomes using parameters that were chosen to match the default parameters of the CLC Bio Genomics Workstation including a mismatch cost of 2, indel costs of 3 , and a similarity fraction of 0.8 over a length fraction of 0.5 . An E-value cutoff of 1e-3 was used to reduce the chance of false positives.

Rolling cycle amplification (RCA), PCR validation, and full-length amplification of viral genomic DNA molecule. To confirm the HTS result, TNA aliquots from the NP and BB source vines were subjected to RCA (Inoue-Nagata et al. 2004) using a TempliPhi Amplification Kit (GE Healthcare Life Sciences, Uppsala, Sweden) as described in the manufacturer's protocol. The RCA products were monomerized with $S b f$ I and HincII restriction enzymes (New England BioLabs, USA) that were predicted to be single cutters and selected based on in silico analysis of the derived HTS sequences performed with the NEBcutter V2.0 software (http://nc2.neb.com/NEBcutter2/). The digested products were separated by electrophoresis on a $1.5 \%$ agarose gel and Trisacetate-EDTA (TAE) buffer and DNA bands in the approximately $3 \mathrm{~kb}$ range were gel-eluted with the Zymoclean Gel DNA Recovery Kit (Zymo Research Corporation, Irvine, CA) from each sample. The full viral genome sequence was determined in two independent labs using two complementary approaches. In the first approach conducted at the FPS facility, UC-Davis, CA, the full-length viral genome was amplified with Phusion DNA polymerase (ThermoFisher Scientific) using a TNA template and a pair of abutting primers GGVAv950/GGVAc961 (Table 1). The $\sim 3-\mathrm{kb}$ viral genomic DNA fragments obtained from NP and $\mathrm{BB}$ vines were independently gel-eluted as described above and directly subjected to Sanger sequencing using the same primers at the UC-Davis sequencing facility (http://dnaseq.ucdavis.edu). Based on the 
initially obtained sequences, additional primers (data not shown) were designed and utilized for genome-walking using the same TNA template for each sample. In the second approach conducted at the Texas A\&M AgriLife Research \& Extension Center facility, another pair of abutting primers GGVAv1402/GGVAc1438 was designed from the assembled HTS sequences and utilized in PCR to amplify the complete viral genomic DNA molecule from NP and BB using the PrimeSTAR GXL DNA polymerase (Clontech Laboratories, Inc.) and the RCA eluates as template. The obtained DNA amplicons were cloned individually into the pCR2.1 TOPOTA vector and transformed into One Shot TOP10 chemically competent Escherichia coli cells according to the manufacturer's
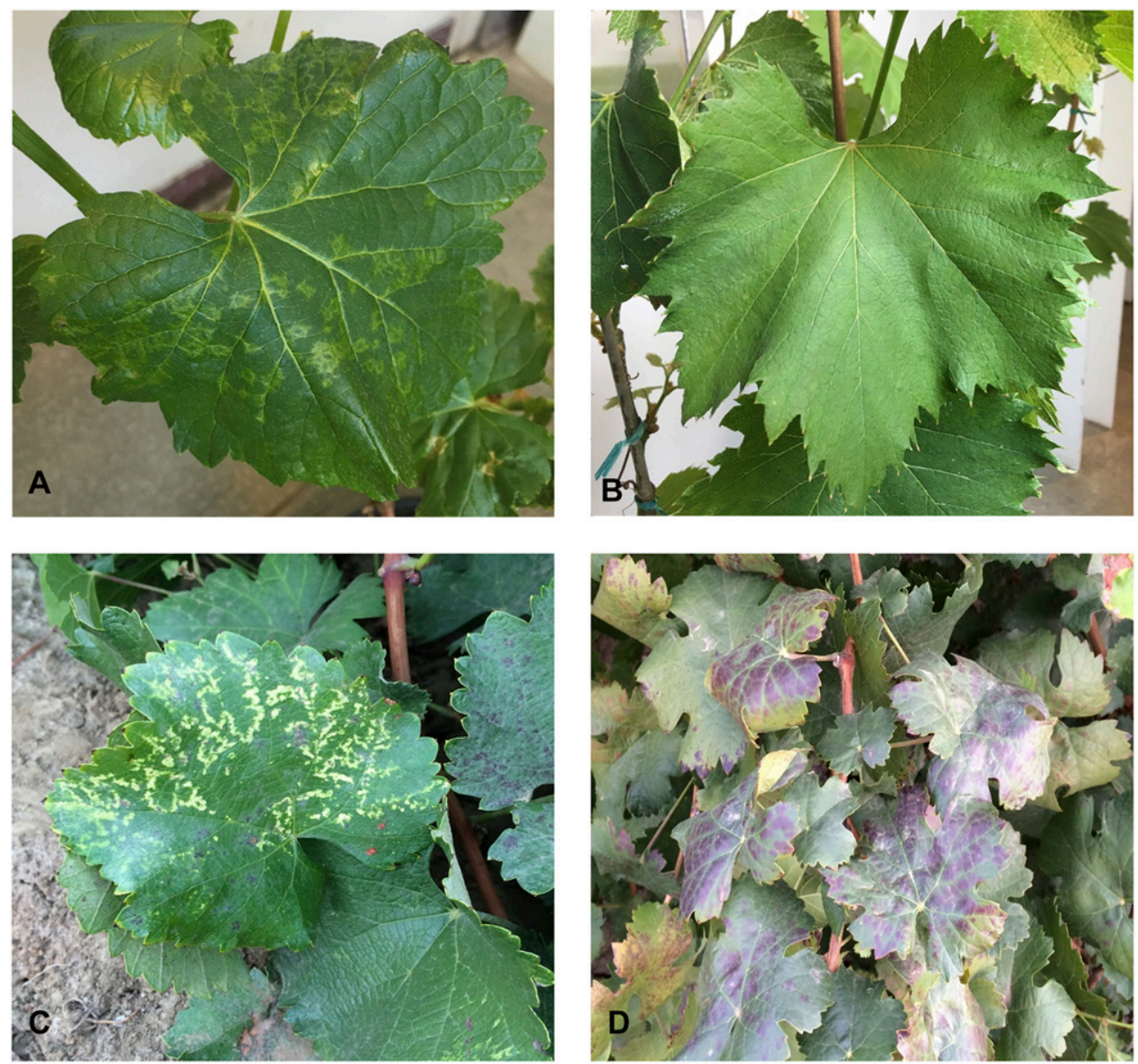

Fig. 1. Symptoms observed on source vines of Vitis vinifera A, 'Nagano Purple' (NP) and B, 'Black Beet' (BB) and corresponding vines of Cabernet franc (Cf) graft-inoculated with bud chips from NP (C) and BB (D) vines. The chlorotic ringspot symptoms observed on the source NP vine (A) was reproduced on the graftinoculated $\mathrm{Cf}$ vine in mixture with leafroll symptoms $(\mathbf{C})$ whereas only leafroll symptoms were produced on $\mathrm{Cf}$ vine $(\mathbf{D})$ graft-inoculated with material from source $\mathrm{BB}$ vine $(\mathbf{D})$

TABLE 1. Primers and probes used in the study for the characterization and routine diagnosis of Grapevine geminivirus A (GGVA) and it defective DNA molecule (GGVA D-DNA)

\begin{tabular}{|c|c|c|c|c|c|c|}
\hline Primer name & Target molecule & ORF & Sequence $\left(5^{\prime}-3^{\prime}\right)^{\mathrm{a}}$ & $\mathrm{T}\left({ }^{\circ} \mathrm{C}\right)$ & $\begin{array}{l}\text { Amplicon } \\
\text { size (bp) }\end{array}$ & Reference \\
\hline GGVAv541 & Genomic DNA and D-DNA & V1 & ggCCAAgAgAAggTTgACCTAT & 56 & 384 & This study \\
\hline GGVAc924 & & V1 & CATgTggggTTATgCTgATC & & & \\
\hline GGVAv2097 & Genomic DNA and D-DNA & $\mathrm{C} 1$ & CgTCCTTgAATCTCССТCTA & 56 & 1,048 & This study \\
\hline GGVAc239 & & IR & gTgggACCACATAACCgACA & & & \\
\hline GGVAv412 & Genomic DNA and D-DNA & $\mathrm{V} 2$ & AAgggAACggCCCAACA & 60 & 63 & This study \\
\hline GGVAc474 & & V1 & gATTTCCTCTTTCTCggATTgAAg & & & \\
\hline Probev430 & & V1 & CTCATAgATTggATCCATgg & & & \\
\hline GGVAv950 & Parental virus and D-DNA & V1 & AAgTCCTACCACgTgCTgAg & 56 & 2,905 & This study \\
\hline GGVAc961 & & V1 & TggTAggACTTggTCATCgA & & & \\
\hline GGVAv1402 & Genomic DNA alone & $\mathrm{C} 3$ & CgTCCAgACCCTgTATgTTATC & 55 & 2,905 & This study \\
\hline GGVAc1438 & & $\mathrm{C} 3$ & gCTACACAAATgCTggATAAC & & & \\
\hline GGVA D-DNAv1246 & D-DNA alone & $\mathrm{C} 1$ & CACTTCgAAACTTgAAATCCC & 55 & 1,559 & This study \\
\hline GGVA D-DNAc1279 & & $\mathrm{C} 1$ & gAgATTCAAggACgggATT & & & \\
\hline PBL1v2040 & DNA-B & $\mathrm{BC} 1$ & gCCTCTgCAgCARTgRTCKATCTTCATACA & & & Rojas et al. 1993 \\
\hline PCRc1 & & IR & CTAgCTgCAgCATATTTACRARWATgCCA & 50 & 600 & \\
\hline PCRc154 & & IR & ggTAATATTATAHCggATgg & 50 & 750 & \\
\hline Beta01 & DNA- $\beta$ & IR & ggTACCACTACgCTACgCAgCAgCC & 50 & 1,350 & Briddon et al. 2002 \\
\hline Beta02 & & IR & CACATggggACCCTCCCATCCATgg & & & \\
\hline
\end{tabular}

${ }^{a}$ The following IUB group codes were used to identify redundancies: $K=G+T, W=A+T, R=A+G, H=A+C+T$. 
protocols (Life Technologies). Screening, selection, plasmid isolations and sequencing of positive transformants were performed as described previously (Mulenga et al. 2016). An additional pair of primers (data not shown) was designed to genome-walk the plasmid DNA samples to obtain the complete viral DNA genome sequences from each isolate. Using this approach, the complete virus genome was also determined from three additional grapevine cultivars.

Search for the presence of additional genomic components and subviral agents. The occurrence of genomic components possibly corresponding to DNA-B and DNA- $\beta$ satellite DNA molecules was investigated. For this purpose, two pairs of degenerate DNA-B-specific primers (Rojas et al. 1993) and a pair of DNA- $\beta$-specific primers (Briddon et al. 2002) were used in PCR. Additionally, an $\sim 1.5-\mathrm{kb}$ DNA band representing a unique restriction digestion product produced by HincII digestion only from isolate NP (Fig. 2A) was gel-eluted, A-tailed, cloned, and sequenced as described previously (Alabi et al. 2016b). Based on the sequences obtained, a pair of abutting primers GGVA DDNAv1246/GGVA D-DNAc1279 was designed from aligned sequences of the subviral DNA molecule and the full-length viral DNA sequences (obtained above) to specifically target the subviral DNA molecule. The amplified $\sim 1.5$-kb DNA band (Fig. $2 \mathrm{~B}$ ) was cloned and sequenced as described above.

Analysis of viral and subviral DNA sequences. Sequence fragments corresponding to each DNA amplicon were edited and assembled as described previously (Alabi et al. 2016b). Each assembled DNA molecule was subjected to blastn analysis (Altschul et al. 1990) to confirm its viral origin and to search the global database for homologous sequences. The programs ORF Finder (https://www.ncbi.nlm.nih.gov/orffinder/) and Pfam (http:// pfam.xfam.org/) were used for the identification of conserved protein domains (Finn et al. 2014) encoded by each genomic DNA molecule. The sequence matches for each predicted protein product were determined using the SmartBLAST algorithm of the ORF Finder. Nucleotide and amino acid sequence alignments were generated with the MUSCLE alignment program (http://www.ebi. ac.uk/Tools $/ \mathrm{msa} / \mathrm{muscle} /$ ) and the aligned sequences were used for pairwise comparisons and phylogenetic analysis using the approaches and suite of programs described in Alabi et al. (2016b).

Phylogenetic analyses were conducted using the neighborjoining, minimum evolution, and maximum likelihood methods from Molecular Evolutionary Genetic Analysis software MEGA version 6 (Tamura et al. 2013) based on complete genome nucleotide sequences and derived coat protein and replicationassociated protein amino acid sequences of the viral genomic DNA. Only the neighbor-joining trees are presented since all three methods generated similar tree topologies.

The software SnapGene Viewer version 3.1.4 (http://www. snapgene.com/) was used to draw the schematic representation of the circular genomes of the genomic and subviral DNA molecules and the NucPred program (Brameier et al. 2007) was used to identify the CP-encoded nuclear localization signal of the novel virus.

Development of conventional and Taqman qPCR assays for detection of GGVA. To enable routine diagnosis of the novel virus in epidemiological studies and to explore its prevalence, complete virus genome sequences of seven GGVA isolates (GenBank accession numbers KX570607 to KX570618) aligned as described above were used to design a primer pair from the coat protein (CP) gene (V1 ORF) for conventional PCR and Taqmanbased qPCR assays (Table 1). The primer pair GGVAv541/ GGVAc924 was designed to amplify 384-bp CP-specific DNA fragments from the viral genomic and defective DNA molecules by conventional PCR (Table 1). For the qPCR assay, the primer pair GGVAv412/GGVAc474 along with the probe GGVAv430 was designed to drive the amplification of a 63-bp DNA fragment specific to the CP gene of GGVA (Table 1). The design of primers and probe for the qPCR assay was carried out under criteria set by the Primer Express software (ThermoFisher Scientific) and following the minimal criteria for the design of qPCR assays (Bustin et al. 2009). All qPCR probes were MGB probes, labeled with 5' FAM reporters and a nonfluorescent quencher. Nucleic acid extracts were prepared from leaf petioles as described above and amplification conditions for the conventional PCR assay consisted of one cycle of $94^{\circ} \mathrm{C}$ for $2 \mathrm{~min} ; 35$ cycles of $94^{\circ} \mathrm{C}$ for 30 $\mathrm{s}, 56^{\circ} \mathrm{C}$ for $45 \mathrm{~s}$, and $72^{\circ} \mathrm{C}$ for $1 \mathrm{~min}$; and one cycle of $72^{\circ} \mathrm{C}$ for 5 min. DNA amplicons obtained in conventional PCR were analyzed by agarose gel electrophoresis in TAE buffer and the virus-specific sequences of a select number of amplicons were verified via direct sequencing of gel-eluted DNA fragments at the UC-Davis sequencing facility (http://dnaseq.ucdavis.edu). Cycling conditions for qPCR were $50^{\circ} \mathrm{C}$ for $2 \mathrm{~min}, 95^{\circ} \mathrm{C}$ for $20 \mathrm{~s}$, the 40 cycles at $95^{\circ} \mathrm{C}$ for $1 \mathrm{~s}$ and $60^{\circ}$ for $20 \mathrm{~s}$. All samples were analyzed on a QuantStudio 6 Flex Real-Time PCR System

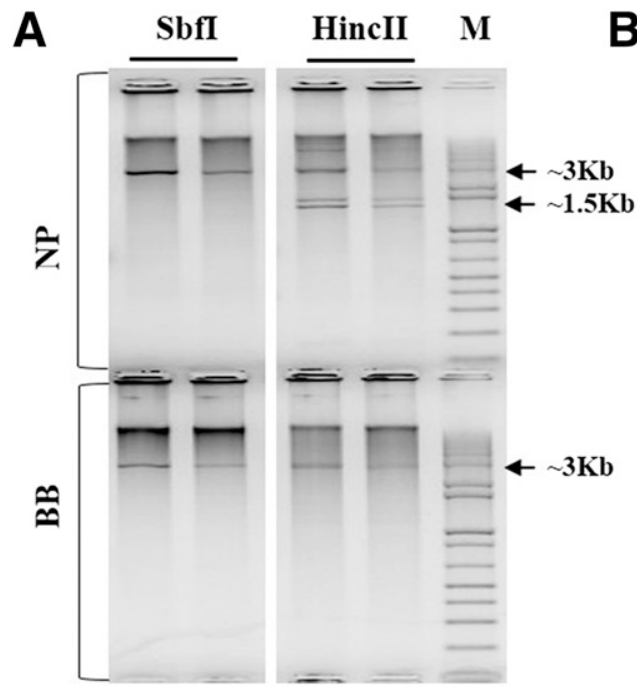

B

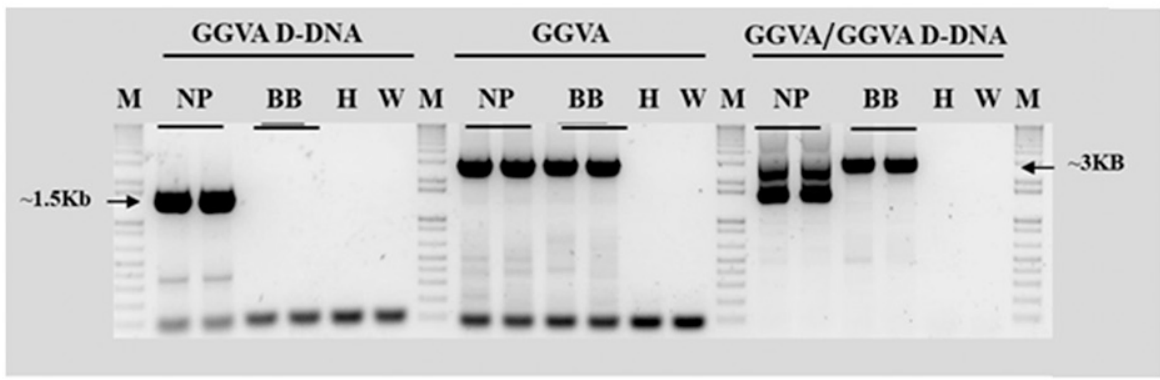

Fig. 2. A, Restriction enzyme digestion of rolling cycle amplification products of DNA extract from Vitis vinifera 'Nagano Purple' (NP) and 'Black Beet' (BB). Both enzymes SbfI and HincII produced a DNA product in the $\sim 3$-kb size range from NP and BB, whereas the enzyme HincII produced additional bands of $\sim 1.5$-kb only from NP. B, PCR amplification of virus-specific bands corresponding to the Grapevine geminivirus A genomic (GGVA) and defective (GGVA D-DNA) molecules from NP and BB vines using pairs of molecule-specific abutting primers (Table 1). A third pair of abutting primers could simultaneously amplify both GGVA and GGVA D-DNA when present in the same NP vines. M: 1-kb Plus DNA Ladder (ThermoFisher Scientific). 
(ThermoFisher Scientific). The data were analyzed both quantitatively by measuring the quantitative cycle $(\mathrm{Cq})$ in a Microsoft Excel program and graphically by an amplification plot. The $\mathrm{Cq}$ is defined as the cycle in which there is a significant increase in reporter signal above the threshold; therefore, it is related to the initial amount of DNA target in the sample (Bustin et al. 2009).

Standard curves were generated by creating five sets of 10 -fold serial dilutions and plotting the $\mathrm{Cq}$ value against the logarithm of the concentration for the exponential phase of the reaction. A trend line was added to this data by simple linear regression (Bustin et al. 2009). The amplification efficiency (E) of all assays was calculated from the slope of a standard curve generated on a 10 -fold dilution in triplicate for every cDNA sample using the formula $\mathrm{E}=10(-1 /$ slope).

Screening for GGVA. A total of 1,262 vines were sampled from the National Clonal Germplasm Repository (NCGR), the Davis Grapevine Virus Collection (DGVC), the FPS Introduction Pipeline, and commercial vineyards. The NCGR sampling was biased in favor of source vines introduced from Asian countries since the initially characterized virus isolates NP and BB originated from this region.

\section{RESULTS}

Plant material. Systemic virus-like chlorotic ringspot symptoms were observed on young to mid-age leaves of all four potted $\mathrm{NP}$ vines (Fig. 1A). In contrast, no symptoms were observed on leaves of all four potted BB vines of the same age (Fig. 1B). Since the chlorotic ringspot symptoms observed on the NP vines are not characteristic of known grapevine viruses, it was hypothesized that the $V$. vinifera cultivar NP might harbor a new uncharacterized virus, thus making this sample a prime candidate for HTS. Cultivar BB was also advanced for HTS for comparative analysis to further decipher the etiology of the disease observed on the NP vines.

Virus detection. Results of the RT-qPCR screening for known grapevine pathogens and the HTS analysis led to the detection of multiple virus and viroid species in mixed infections of different proportions in NP and BB vines. Four viruses (GLRaV-3, GFkV, GSyV-1, and GFabV) (Al Rwahnih et al. 2016) and two viroid species (Hop stunt viroid and Grapevine yellow speckle viroid-1) were detected in both NP and BB. In addition, GLRaV-2 was detected in NP while GVE, GRSPaV, and GRVFV were detected in $\mathrm{BB}$ vines. Both vines were negative for the eleven other infectious agents (GLRaV-1, GLRaV-4, GLRaV-7, GFLV, TRSV, ToRSV, GVA, GVB, GVD, phytoplasmas, and X. fastidiosa) that were included in the pathogen screen assays.

Analysis of HTS data. The total number of trimmed sequence reads recovered from $\mathrm{NP}$ and $\mathrm{BB}$ cDNA libraries ranged from 32 to 34 million and their analysis resulted in the assembly of 35,030 to 35,770 contigs from each library. The annotation and tblastx analyses of these contigs against the reference virus genomes in the NCBI database led to the recovery of genome sequences of all

TABLE 2. Recovery of sequence reads representing novel viruses detected from grapevine (Vitis vinifera) accessions Nagano Purple (NP) and Black Beet (BB) via high-throughput sequencing

\begin{tabular}{llccr}
\hline & & & \multicolumn{2}{c}{ Contigs } \\
\cline { 4 - 5 } Sample & \multicolumn{1}{c}{ Virus $^{\mathrm{a}}$} & Mapped reads & Number & \multicolumn{1}{c}{ Size } \\
\hline NP & GGVA & 1,568 & 3 & $271-1,164$ \\
& GFabV RNA1 & 71,280 & 2 & $1,615-4,077$ \\
& GFabV RNA2 & 33,927 & 2 & $1,224-1,852$ \\
BB & GGVA & 2,940 & 4 & $266-1,063$ \\
& GFabV RNA1 & 117,165 & 1 & 3,082 \\
& GFabV RNA2 & 157,433 & 1 & 5,755 \\
\hline
\end{tabular}

a GGVA, Grapevine geminivirus A; GFabV, Grapevine fabavirus (Al Rwahnih et al. 2016). known grapevine viruses that were previously detected from both vines by RT-qPCR as stated earlier. Further analysis of the HTS contigs led to the recovery of the near complete RNA1 and RNA2 sequences of the recently described Grapevine fabavirus in both NP and BB vines (Table 2) (Al Rwahnih et al. 2016). The first indication of the occurrence of geminivirus-like contigs in the cDNA libraries derived from isolates NP and BB is the recognition of the highly conserved geminiviral nonanucleotide sequence "TAATATT $\downarrow$ AC" among the non-Vitis contigs derived from both isolates. Subsequently, multiple geminivirus-specific contigs were recovered from both NP and BB vines (Table 2). A blastx analysis of the approximately 2,905 nucleotides common to both isolates confirmed its geminiviral origin and produced significant alignments with several replication-associated putative conserved domains (data not shown).

Identification of a novel DNA virus and its defective DNA molecule in grapevine. The HTS results were independently validated via recovery of the complete genome of the novel DNA virus from isolates NP and BB by Sanger Sequencing performed either on direct PCR amplicons (Fig. 2B) or plasmid DNA from cloned DNA products that were obtained with abutting primers (Table 1) as described above. Analysis of multiple independent clones from isolates NP (three clones) and BB (four clones) yielded complete ssDNA genome sequences (GenBank accession numbers KX570607 and KX560609) that ranged in size from 2,903 to $2,907 \mathrm{nt}$ and were almost identical (98 to $100 \%$ ) to each other and to corresponding HTS-derived sequences. The $2 \%$ divergence among the nine NP and BB GGVA clones was mostly a result of variations in the lengths of the intergenic region sequences. The complete viral genomic DNA sequences obtained from nine additional cultivars (GenBank accession numbers KX570610 to KX560618) were of the same size range and identity levels as sequences derived from isolates $\mathrm{NP}$ and $\mathrm{BB}$. In addition, cloning and sequence analysis of the $\sim 1.55-\mathrm{kb}$ HincII-derived DNA fragment from NP (Fig. 2A), and subsequent independent validation using a pair of abutting primers specifically designed for the subviral DNA molecule, led to the recovery of a naturally occurring defective form of GGVA that is about half the size $(1,559$ nt) of the full-length viral genomic DNA sequence. This subviral molecule is tentatively named GGVA D-DNA since its role in virushost modulation is yet to be described. In agreement with the results of the restriction enzyme digestion assays, GGVA D-DNA was detected only in NP (but not BB) by PCR using the pair of abutting primers capable of specific detection of the defective DNA molecule (Table 1). Analysis of the subviral DNA molecule showed that it was derived directly from, and arose as a result of, deletions of $\sim 46 \%$ of the genome sequence of the monopartitite GGVA (parental) virus (Supplementary Fig. S1). Further analysis of all four independent NP clones of GGVA D-DNA (GenBank accession number KX570608) revealed that they are $100 \%$ identical to each other but shared only 52 to $53 \%$ genome length identities with the parental virus due to the deletion in the rep-associated sequences. No insertion from any other source was found within the genome sequence of GGVA D-DNA. Several attempts to amplify a DNA-B component and the DNA- $\beta$ satellite molecule from both isolates using published universal primers and PCR conditions (Rojas et al. 1993; Briddon et al. 2002) were not successful, indicating a lack of association of both molecules with GGVA. These results suggest that GGVA is a monopartite ssDNA virus associated with a defective ssDNA molecule.

Genome organization and molecular properties of GGVA. Like most members of the family Geminiviridae, the stem-loop sequence of the intergenic region of GGVA contains the nonanucleotide sequence "TAATATT $\downarrow$ AC" (Fig. 3C). A blastn search of the complete genome sequences of GGVA confirmed its geminiviral origin and the most resemblance to several members of the genus Begomovirus albeit at low genome coverage (66 to $82 \%$ identity; query coverage, 12 to $38 \%$; E value, 1e-62 to $4 \mathrm{e}-113)$. Two 
virion-sense (V1 and V2) and four complementary-sense (C1 to C4) putative translation products were identified in the circular ssDNA genome of GGVA (Fig. 3A; Table 3). A blastp analysis of the predicted proteins of GGVA showed similarities as well as differences with viruses belonging to different genera in the family Geminiviridae. For instance, whereas most of the complementarysense ORFs of GGVA show greater resemblance to begomoviruses, the virion-sense ORFs are more related to the recently characterized Apple geminivirus (AGV [KM386645]) (Liang et al. 2015) whose genus designation is yet to be determined. The ORF V1 is $771 \mathrm{nt}$ in length and its translation product $(256 \mathrm{aa} ; 29.3 \mathrm{kDa})$ is most identical to the CP of AGV ( $48 \%$ identity; query coverage, $100 \%$; $\mathrm{E}$ value, 3e-86). Similarly, the translation product (103 aa; $11.7 \mathrm{kDa}$ ) of the $312 \mathrm{nt}$ long ORF V2 of GGVA is most identical to the V2 protein of AGV (52\% identity; query coverage, $63 \%$; $\mathrm{E}$ value, 1e-18). The predicted CP-encoded nuclear localization signal (NLS) was identified as "NPRKRKSFA" (E value: 0.81).

Unlike the virion-sense ORFs, the complimentary-sense proteins of GGVA are more identical to their homologs in two of the seven currently recognized genera in the family Geminiviridae. The translation product of ORF C1 $(1,212 \mathrm{nt} ; 403 \mathrm{aa} ; 45.1 \mathrm{kDa})$ is most closely related to the replication-associated protein (AC1) of the begomovirus Tomato yellow leaf curl Thailand virus (TYLCTHVD [AF206674]; 63\% aa identity; query coverage, 91\%; E value, 6e179) but its predicted $\mathrm{C} 2$ protein $(420 \mathrm{nt} ; 139 \mathrm{aa} ; 15.6 \mathrm{kDa})$ is most identical to the transcriptional activator protein (AC2) of African cassava mosaic virus (ACMV [X17095]; 36\% aa identity; query coverage, 92\%; E value, 2e-15), another begomovirus. Similarly, the predicted ORFs C3 of GGVA (429 nt; $142 \mathrm{aa} ; 16.4 \mathrm{kDa}$ ) is most identical to the replication enhancer protein (AC3) of another begomovirus Indian cassava mosaic virus (ICMV [Z24758]; 39\% aa identity; query coverage, $94 \%$; E value, 1e-26). In contrast to ORFs C1 to C3, the predicted ORF C4 of GGVA (258 nt; 85 aa; $9.9 \mathrm{kDa}$ ) shared the greatest resemblance to the $\mathrm{C} 4$ protein of Beet curly top virus (BCTV [M24597]; 64\% aa identity; query coverage, $100 \%$; E value, 8e-29), a member of the genus Curtovirus. An alignment of the $\mathrm{N}$-terminal portion of the replication-associated protein sequence of GGVA showed that it also contains the dsRNA- binding motifs FLTYP (motif I), HLH (motif II), and YIEKD (motif III) that have been reported in other geminiviruses and are implicated in protein conformational changes and viral DNA cleavage in addition to the so-called GRS domain (Fig. 4; Nash et al. 2011).

In pairwise comparisons, the complete genome sequence of GGVA shared maximum identities (50 to 51\%) with six begomoviruses (Table 4), its complete CP amino acid sequence was most identical $(48 \%)$ to corresponding sequences of $\mathrm{AGV}$, while its complete rep protein sequence shared maximum identities (50 to 58\%) with AGV, Beet curly top virus (BCTV), Tomato pseudo-curly top virus (TPCTV), and several begomoviruses (Table 4). Taken together, these results showed that GGVA is a unique novel member of the plant virus family Geminiviridae sharing sequence characteristics with members of diverse genera within the family.

Genome organization and molecular properties of GGVA D-DNA. Like its parental virus, the stem-loop sequence of the intergenic region of the GGVA D-DNA molecule also contains the geminiviral nonanucleotide "TAATATT $\downarrow$ AC" (Fig. 3C). Further analysis revealed that the $\sim 46 \%$ deletion in the genome parental virus that gave rise to GGVA D-DNA occurred due to an excision of ORFs C2, C3, and C4, and a near complete (82\%) loss of the $\mathrm{C}$-terminal amino acid sequences of ORF $\mathrm{C} 1$ corresponding to nucleotide positions 1265 to 2679 on the GGVA genome (Fig. 3B). As a result, only one of the dsRNA-binding motifs (FLTYP) was retained by in the N-terminal portion of the GGVA D-DNA Rep protein sequences. Interestingly, both virion-sense ORFs V1 and V2 were not disrupted (Table 3; Fig. 3B), suggesting that the defective DNA molecule of GGVA could potentially be encapsidated to form isometric particles thus giving rise to the probability of its possible transmission by a yet-to-be-identified vector. Similar observations have been made for defective DNA molecules associated with Ageratum yellow vein virus (AYVV) (Stanley et al. 1997) and Cotton leaf curl virus (CLCuV) (Liu et al. 1998). In addition, GGVA D-DNA also retained the CP-encoded importin $\alpha$-dependent NLS, suggesting that it is also capable of being shuttled in and out of the nucleus (Fontes et al. 2004; Rojas et al.

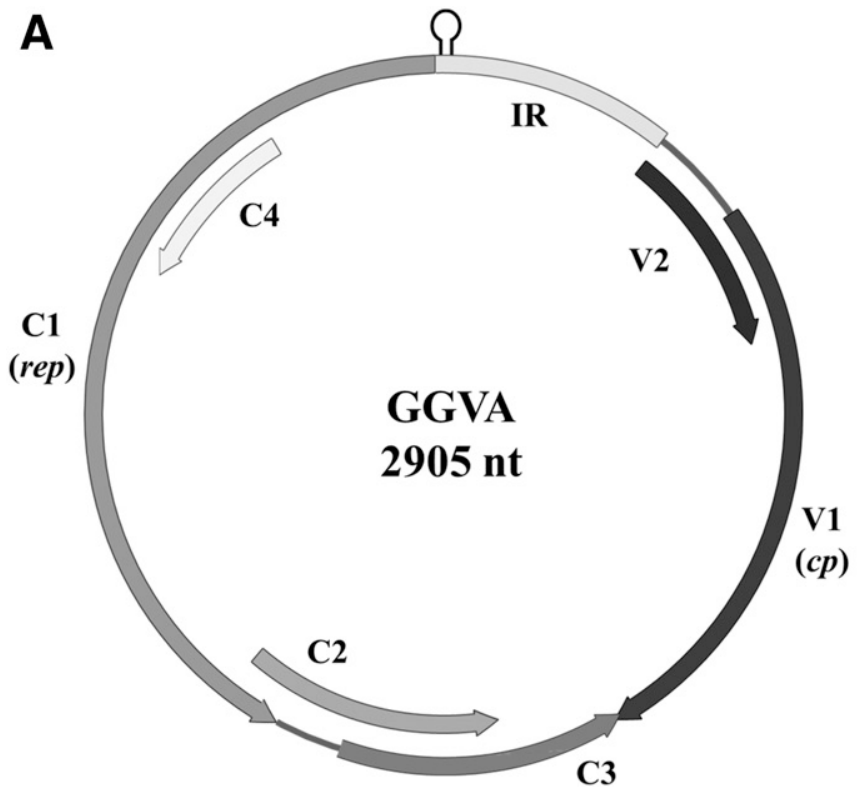

B
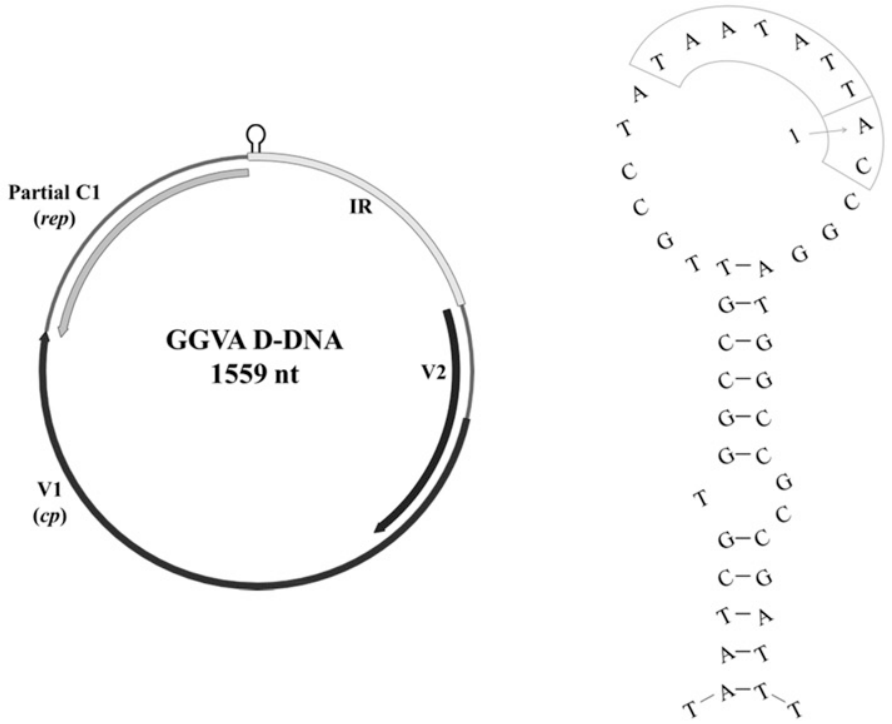

Fig. 3. Genome maps of the genomic A, and defective B, circular ssDNA molecules of Grapevine geminivirus A (GGVA). Arrows denote the virion-sense (V) and complementary-sense (C) geminiviral genes encoded by each molecule. IR, intergenic region sequences; V1, coat protein; V2, pre-coat protein; C1, replicationassociated protein; C2, transcriptional activator protein; C3, replication enhancer protein; C4, host activator protein. C, The stem-loop in the IR of GGVA and GGVA D-DNA is depicted with the conserved geminiviral nonanucleotide sequence "TAATATT $\downarrow$ AC" shown in gray arc box (nucleotide position 2899 to 2). Number 1 (gray arrow) indicates position 1 in the viral genome corresponding to the predicted replication origin of the viral DNA. 
2001). These results represent the first report of the association of a defective DNA molecule with a grapevine virus.

Phylogenetic relationships between GGVA and other taxa in the family Geminiviridae Phylogenetic relationships inferred using aligned complete genome sequences of GGVA, representatives of the currently recognized genera in the family Geminiviridae, as well as yet to be classified members of the family revealed contrasting evolutionary history for the virus. Based on complete virus genome sequences, GGVA formed a distinct cluster sandwiched between AGV and TPCTV on the neighbor-joining

TABLE 3. Genome features of type isolates of Grapevine geminivirus A (GGVA) and its defective DNA molecule (GGVA D-DNA)

\begin{tabular}{|c|c|c|c|c|c|c|c|}
\hline Isolate & Genome length (nt) & Protein $\mathrm{ID}^{\mathrm{a}}$ & Length (nt) & Length (aa) & $\begin{array}{c}\text { Molecular } \\
\text { weight (kDa) }\end{array}$ & Start & End \\
\hline \multirow[t]{7}{*}{ GGVA-NP } & \multirow[t]{7}{*}{2,905} & Rep/C1 & 1,212 & 403 & 45.1 & 1,683 & 2,894 \\
\hline & & $\mathrm{CP} / \mathrm{V} 1$ & 771 & 256 & 29.3 & 446 & 1,216 \\
\hline & & Ren/C3 & 429 & 142 & 16.4 & 1,213 & 1,641 \\
\hline & & TrAP/C2 & 420 & 139 & 15.6 & 1,364 & 1,783 \\
\hline & & $\mathrm{V} 2$ & 312 & 103 & 11.7 & 313 & 624 \\
\hline & & $\mathrm{C} 4$ & 258 & 85 & 9.9 & 2,390 & 2,647 \\
\hline & & IR/NCR & 323 & NA & NA & $1 \ldots 312$ & $2,895 \ldots 2,905$ \\
\hline \multirow[t]{4}{*}{ GGVA D-DNA (NP-4-1) } & \multirow[t]{4}{*}{1,559} & $\mathrm{CP} / \mathrm{V} 1$ & 771 & 256 & 29.3 & 446 & 1,216 \\
\hline & & N-terminal Rep/C1 & 336 & 111 & 12.5 & 1,213 & 1,548 \\
\hline & & V2 & 312 & 103 & 11.7 & 313 & 624 \\
\hline & & IR/NCR & 323 & NA & NA & $1 \ldots 312$ & $1,549 \ldots 1,559$ \\
\hline
\end{tabular}

${ }^{a}$ Rep, replication-associated protein; CP, coat protein; Ren, replication enhancer protein; TrAP, transcriptional activator protein; IR, intergenic region; and NCR, noncoding region.

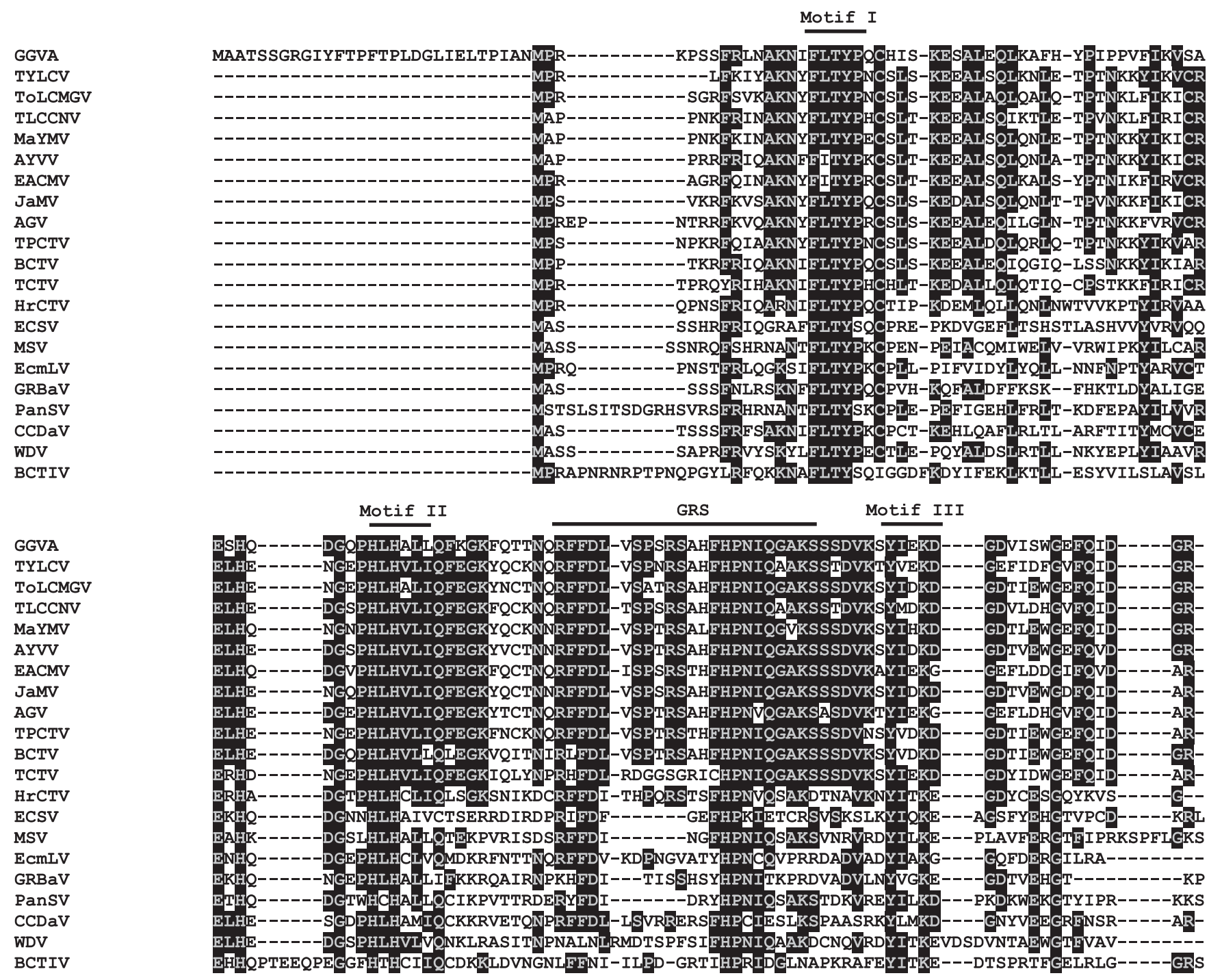

Fig. 4. Multiple alignment of the N-terminal portion of Rep protein sequences of Grapevine geminivirus A (GGVA) and other members of the family Geminiviridae highlighting conserved motifs I, II, III, and GRS. AGV, Apple geminivirus; BCTV, Beet curly top virus; HrCTV, Horseradish curly top virus; SCTAV, Spinach curly top Arizona virus; BCTIV, Beet curly top Iran virus; TCTV, Turnip curly top virus; ECSV, Eragrostis curvula streak virus; WDV, Wheat dwarf virus; MSV, Maize streak virus; PanSV, Panicum streak virus; TPCTV, Tomato pseudo-curly top virus; GRBaV, Grapevine red blotch-associated virus; FbSLSV; French bean severe leaf curl virus; EcmLV, Euphorbia caput-medusae latent virus; MMDaV, Mulberry mosaic dwarf-associated virus; CCDaV, Citrus chlorotic dwarfassociated virus; TLCCNV, Tomato leaf curl China virus; ELCV, Euphorbia leaf curl virus; ToLCMGV, Tomato leaf curl Madagascar virus; EACMV, East African cassava mosaic virus; TYLCCNV, Tomato yellow leaf curl China virus; AYVV, Ageratum yellow vein virus; and ToLCHaV, Tomato leaf curl Hainan virus. 
phylogenetic tree (Fig. 5C). However, it clustered more tightly with $\mathrm{AGV}$ in a cluster very distinct from those formed by other geminiviruses but sandwiched between curtoviruses and begomoviruses on the $\mathrm{CP}$ amino acid-based tree (Fig. 5A). The rep (C1 protein) based tree showed that GGVA isolates NP and BB represent a distinct genus-level clade sandwiched between clades formed by turncurtoviruses and begomoviruses/AGV (Fig. 5B). Similar topologies were observed on phylogenetic trees constructed using

TABLE 4. Size and range of complete genome and gene-specific amino acid sequences between Grapevine geminivirus A (GGVA) isolate Nagano Purple and GGVA isolate Black Beet (BB) along with published viruses representing the species diversity within the family Geminiviridae

\begin{tabular}{|c|c|c|c|c|c|c|c|c|}
\hline \multirow[b]{2}{*}{ Virus $^{\mathrm{a}}$} & \multirow[b]{2}{*}{ Genus } & \multirow[b]{2}{*}{ Host Type } & \multirow[b]{2}{*}{ Vector } & \multirow{2}{*}{$\begin{array}{c}\text { GenBank accession } \\
\text { number }\end{array}$} & \multirow[b]{2}{*}{ Genome size (nt) } & \multirow{2}{*}{$\begin{array}{l}\text { Genome sequence } \\
\text { identity }(\%)\end{array}$} & \multicolumn{2}{|c|}{$\begin{array}{l}\text { Amino acid } \\
\text { sequence } \\
\text { identity }(\%)\end{array}$} \\
\hline & & & & & & & $\mathrm{CP}$ & Rep \\
\hline GGVA-BB & Unassigned & Dicot & Unknown & KX570609 & 2,905 & 97.9 & 99.2 & 98.0 \\
\hline AGV & Unassigned & Dicot & Unknown & KM386645 & 2,932 & 46.0 & 47.6 & 50.8 \\
\hline BCTV & Curtovirus & Dicot & Leafhopper & AF379637 & 3,038 & 38.2 & 12.9 & 49.7 \\
\hline $\mathrm{HrCTV}$ & Curtovirus & Dicot & Leafhopper & U49907 & 3,080 & 34.9 & 14.0 & 41.3 \\
\hline SCTAV & Becurtovirus & Dicot & Leafhopper & HQ443515 & 2,860 & 27.9 & 13.7 & 17.9 \\
\hline BCTIV & Becurtovirus & Dicot & Leafhopper & EU273818 & 2,845 & 28.1 & 12.5 & 16.7 \\
\hline TCTV & Turncurtovirus & Dicot & Leafhopper & KT388064 & 2,969 & 36.2 & 13.7 & 47.9 \\
\hline ECSV & Eragrovirus & Monocot & Leafhopper & FJ665629 & 2,746 & 32.2 & 12.2 & 35.3 \\
\hline WDV & Mastrevirus & Monocot & Leafhopper & X02869 & 2,749 & 27.4 & 10.5 & 21.7 \\
\hline MSV & Mastrevirus & Monocot & Leafhopper & AF329881 & 2,689 & 27.0 & 12.8 & 22.9 \\
\hline PanSV & Mastrevirus & Monocot & Leafhopper & L39638 & 2,705 & 26.4 & 13.9 & 15.5 \\
\hline TPCTV & Topocuvirus & Dicot & Treehopper & X84735 & 2,861 & 39.1 & 12.8 & 50.8 \\
\hline GRBaV & Unassigned & Dicot & Treehopper & JQ901105 & 3,206 & 30.0 & 14.2 & 25.5 \\
\hline FbSLCV & Unassigned & Dicot & Unknown & JX094280 & 2,771 & 27.9 & 15.0 & 22.8 \\
\hline EcmLV & Capulavirus $^{\mathrm{b}}$ & Dicot & Unknown & HF921477 & 2,650 & 26.2 & 14.2 & 25.3 \\
\hline MMDaV & Unassigned & Dicot & Unknown & KP303687 & 2,952 & 29.1 & 14.4 & 25.9 \\
\hline $\mathrm{CCDaV}$ & Unassigned & Dicot & Whitefly & JQ920490 & 3,640 & 27.9 & 11.5 & 22.2 \\
\hline TLCCNV & Begomovirus & Dicot & Whitefly & AJ704603 & 2,733 & 50.6 & 11.9 & 56.6 \\
\hline ELCV & Begomovirus & Dicot & Whitefly & AJ558121 & 2,746 & 50.4 & 14.3 & 58.0 \\
\hline ToLCMGV & Begomovirus & Dicot & Whitefly & AJ865339 & 2,775 & 50.5 & 12.9 & 56.9 \\
\hline EACMV & Begomovirus & Dicot & Whitefly & JF909175 & 2,801 & 47.3 & 14.3 & 53.9 \\
\hline TYLCCNV & Begomovirus & Dicot & Whitefly & KC189893 & 2,737 & 49.9 & 12.6 & 57.4 \\
\hline AYVV & Begomovirus & Dicot & Whitefly & KC810890 & 2,759 & 49.9 & 15.0 & 54.7 \\
\hline ToLCHaV & Begomovirus & Dicot & Whitefly & HQ162270 & 2,740 & 50.2 & 13.6 & 57.1 \\
\hline
\end{tabular}

a AGV, Apple geminivirus; BCTV, Beet curly top virus; HrCTV, Horseradish curly top virus; SCTAV, Spinach curly top Arizona virus; BCTIV, Beet curly top Iran virus; TCTV, Turnip curly top virus; ECSV, Eragrostis curvula streak virus; WDV, Wheat dwarf virus; MSV, Maize streak virus; PanSV, Panicum streak virus; TPCTV, Tomato pseudo-curly top virus; GRBaV, Grapevine red blotch-associated virus; FbSLCV; French bean severe leaf curl virus; EcmLV, Euphorbia caputmedusae latent virus; MMDaV, Mulberry mosaic dwarf-associated virus; CCDaV, Citrus chlorotic dwarf-associated virus; TLCCNV, Tomato leaf curl China virus; ELCV, Euphorbia leaf curl virus; ToLCMGV, Tomato leaf curl Madagascar virus; EACMV, East African cassava mosaic virus; TYLCCNV, Tomato yellow leaf curl China virus; AYVV, Ageratum yellow vein virus; and ToLCHaV, Tomato leaf curl Hainan virus.

b Tentative genus.
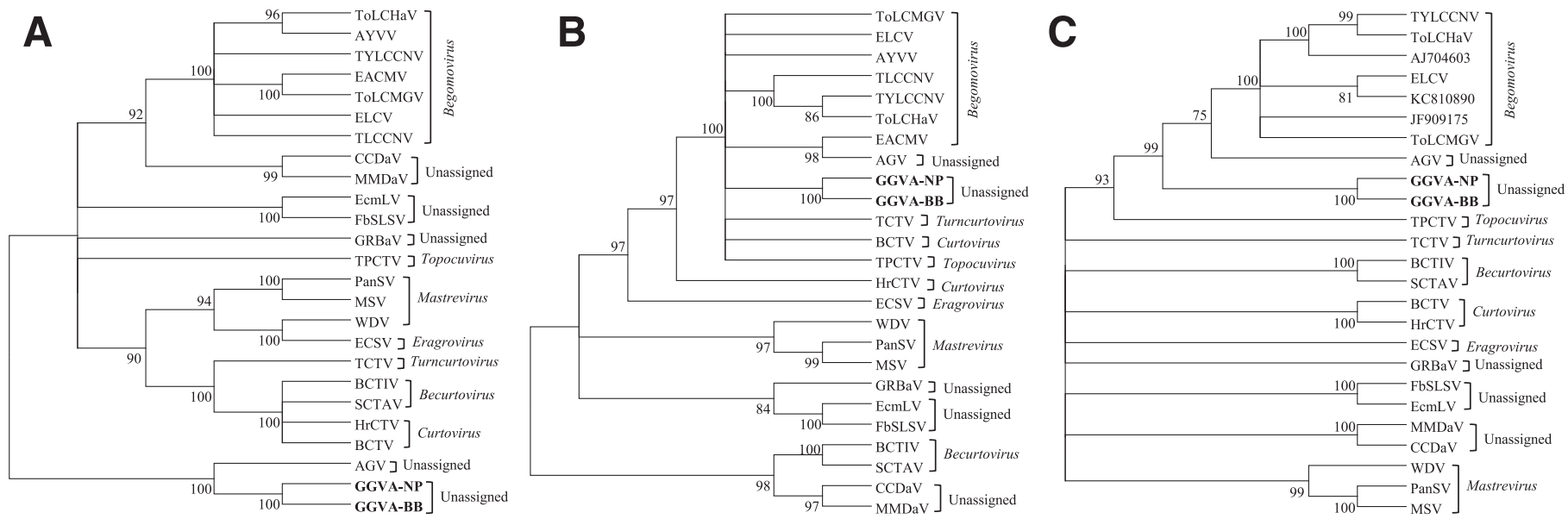

Fig. 5. Unrooted neighbor-joining phylogenetic trees reconstructed from the alignment of the amino acid sequences of $\mathbf{A}$, coat protein, $\mathbf{B}$, rep protein, and $\mathbf{C}$, the full-genome nucleotide sequences of Grapevine geminivirus A (GGVA) and representative members of the family Geminiviridae. The trees were constructed using the MEGA6 program (Tamura et al. 2013) and percent bootstrap values (1,000 replicates) are indicated at the branch internodes. AGV, Apple geminivirus; BCTV, Beet curly top virus; HrCTV, Horseradish curly top virus; SCTAV, Spinach curly top Arizona virus; BCTIV, Beet curly top Iran virus; TCTV, Turnip curly top virus; ECSV, Eragrostis curvula streak virus; WDV, Wheat dwarf virus; MSV, Maize streak virus; PanSV, Panicum streak virus; TPCTV, Tomato pseudo-curly top virus; GRBaV, Grapevine red blotch-associated virus; FbSLCV; French bean severe leaf curl virus; EcmLV, Euphorbia caput-medusae latent virus; MMDaV, Mulberry mosaic dwarf-associated virus; CCDaV, Citrus chlorotic dwarf-associated virus; TLCCNV, Tomato leaf curl China virus; ELCV, Euphorbia leaf curl virus; ToLCMGV, Tomato leaf curl Madagascar virus; EACMV, East African cassava mosaic virus; TYLCCNV, Tomato yellow leaf curl China virus; AYVV, Ageratum yellow vein virus; and ToLCHaV, Tomato leaf curl Hainan virus. 
maximum likelihood and minimum evolution methods (data not shown) thus validating the observed clustering patterns. Similar clustering patterns were observed between genome and protein specific sequence trees derived in this study and corresponding trees generated in other recent studies (Liang et al. 2015; Ma et al. 2015) providing further validity of the results.

GGVA and its defective molecule are graft-transmissible. In bud chip graft transmission assays, GGVA and its co-infecting viruses were successfully transmitted from the NP and BB source onto Cabernet franc $(\mathrm{Cf})$ indicator vines. An indication of the success of the graft transmission assay was the observation of leafroll disease symptoms on leaves of the $\mathrm{Cf}$ indicator vines (Fig. $1 \mathrm{C}$ and D), as would have been predicted by the HTS identification of leafroll viruses in the $\mathrm{NP}$ and $\mathrm{BB}$ source vines. Interestingly, the chlorotic ringspot symptom observed on the NP source was reproduced on the Cf indicator in addition to leafroll disease symptoms (Fig. 1C). In contrast, the Cf grafted with BB source expressed only leafroll disease symptoms (Fig. 1D). Cf materials infected from NP and BB source vines also tested positive by RT-qPCR for other viruses originally identified in the respective vines. However, whereas GGVA was detected from $\mathrm{Cf}$ on both NP and BB sources, GGVA D-DNA was detected only from Cf on the NP source in agreement with the results of the PCR tests. None of the mechanically inoculated herbaceous indicator plants produced discernible virus-like symptoms and all tested negative for GGVA and GGVA D-DNA by PCR (data not shown), indicating that the virus and its defective DNA are not mechanically transmissible to herbaceous plants. These results show that GGVA and its defective DNA molecule are graft-transmissible.

Validation of the qPCR assay. A qPCR assay was developed for the detection of GGVA. The primers and probe for the assay (Table 1) were designed based on alignments of 11 fulllength GGVA genomes derived from multiple grapevine cultivars (Table 5). For assay validation, five 10 -fold serial dilutions of DNA extracted from infected tissue samples and undiluted DNA were subjected to qPCR. As shown in Supplementary Fig. S2A, normal amplification curves were obtained for the DNA dilution series difference. In addition, the standard curve constructed based on the plot of the DNA dilutions against corresponding $\mathrm{Cq}$ values revealed a linear relationship with a regression coefficient $\left(R^{2}\right)$ value of 0.9996 . The primer efficiency (E) value was determined to be 95.22 , indicating that the majority of the target molecules were amplified during the course of the qPCR assay.

Occurrence of GGVA in additional vines from multiple geographical locations. Of the 1,262 samples in the field survey for GGVA, 585 were from the Davis Grapevine Virus Collection (DGVC), 230 were from the USDA National Clonal Germplasm Repository (NCGR) vineyards, 250 were from the FPS Introduction Pipeline, and 197 were from commercial vineyards. The newly developed qPCR assay (Table 1) was used to screen all samples for GGVA. In qPCR tests, 22 vines $(1.74 \%)$ tested positive for GGVA (Table 5). A breakdown of the positive vines by collection type showed that $0.51 \%$ (3 of 585) came from the DGVC, $6.52 \%$ (15 of 230) from the USDA NCGR, and $1.6 \%$ (4 of 250) from the FPS Introduction Pipeline. None of the 197 vines sampled from commercial vineyards tested positive for GGVA. Further analysis of the 22 positive vines indicated that the vines were originally introduced from six countries (Israel $=3$, Japan $=10$, China $=4$, United States $=1$, Hungary $=1$, and South Korea $=3$ ) and were derived from 15 grapevine cultivars (Table 5). Although the overall incidence of GGVA-positive vines (1.74\%) would suggest a low incidence of the virus, the diversity of sources of the positive vines points to a possible global distribution.

\section{DISCUSSION}

It has long been thought that the host range of geminiviruses is limited to herbaceous plants. However, the last few years have witnessed an increase in the number of geminiviruses from woody perennial plant species. The expanding list of geminiviruses characterized from woody host plants includes Citrus chlorotic dwarf-associated virus (CCDaV) (Loconsole et al. 2012), Grapevine red blotch-associated virus (GRBaV) (Al Rwahnih et al. 2013; Krenz et al. 2012; Poojari et al. 2013), Jatropha mosaic virus (JaMV) (Polston et al. 2014), Mulberry mosaic dwarf-associated virus (MMDaV) (Ma et al. 2015), and Apple geminivirus (AGV) (Liang et al. 2015). With the report of yet another putative member of the family Geminiviridae, GGVA, in this study, it is becoming clear that the host range of this economically important plant virus family is more extensive than previously realized. Interestingly, these new groups of geminiviruses are so distantly related to members of the currently recognized genera in the family that they

TABLE 5. Occurrence of Grapevine geminivirus A (GGVA) in a subset of vines from various grapevine germplasm collections maintained by the United States Department of Agriculture (USDA) and Foundation Plant Services (FPS) at the University of California, Davis (UC-Davis), CA

\begin{tabular}{|c|c|c|c|c|c|c|c|c|}
\hline Source & $\begin{array}{l}\text { Plants in } \\
\text { collection }\end{array}$ & Total tested & $\begin{array}{c}\text { Total } \\
\text { positive }\end{array}$ & Variety & Grape type & Country & Location & Accession number \\
\hline UC-Davis GVCa & 788 & 585 & 3 & Tamar & Table/wine & Israel & ARM VSV 9 V19-21 & N/A \\
\hline \multirow[t]{11}{*}{ USDA NCGR ${ }^{b}$} & 5,461 & 230 & 2 & Koshu Sanjaku & Table/wine & Japan & H3 V11, V12 & KX570617 \\
\hline & & & 2 & Muscat Angel & Table & Japan & H3 V37, V38 & N/A \\
\hline & & & 1 & Super Hamburg & Table/wine & Japan & H4 V38 & KX570610 \\
\hline & & & 1 & Pione & Table & Japan & H17 V30 & KX570616 \\
\hline & & & 1 & $\mathrm{~J}-167-045$ & Unknown & China & H42 V51 & N/A \\
\hline & & & 1 & Kyoho & Table & Japan & K9 V10 & KX570612 \\
\hline & & & 2 & Neo-Muscat & Table & Japan & K13 V35, V36 & KX570613 \\
\hline & & & 1 & Longyan & Table/wine & China & L2 V13 & KX570611 \\
\hline & & & 2 & Longyan & Table/wine & China & L13 V21, V22 & N/A \\
\hline & & & 1 & Scolokertek Kiralynoje & Table & Hungary & K7 V8 & KX570618 \\
\hline & & & 1 & Pearl of Zola & Table & United States & K13 V38 & N/A \\
\hline \multirow{4}{*}{$\begin{array}{l}\text { FPS New Introduction } \\
\text { Pipeline }\end{array}$} & N/A & 250 & 1 & Black Beet & Table & South Korea & GH1 N 60 & KX570609 \\
\hline & & & 1 & Nagano Purple & Table & South Korea & GH1 N 60 & $\begin{array}{c}\text { KX570607 } \\
\text { KX570608 }\end{array}$ \\
\hline & & & 1 & Nehelescol & Table & Japan & SC $2 \mathrm{~S} 60$ & KX570615 \\
\hline & & & 1 & Shine Muscat & Table & South Korea & $\mathrm{SC} 2 \mathrm{~S} 70$ & KX570614 \\
\hline $\begin{array}{l}\text { Commercial } \\
\text { vineyards }\end{array}$ & N/A & 197 & N/A & N/A & N/A & N/A & N/A & N/A \\
\hline
\end{tabular}

a UC-Davis Grapevine Virus Collection.

b USDA NCGR, U.S. Department of Agriculture National Clonal Germplasm Repository.

c Accession number for the Nagano Purple GGVA D-DNA genome. 
may represent genus-level members of the family. Consequently, there is a need for a comprehensive review of the taxonomy of the family Geminiviridae to better understand the evolutionary histories and implications of the discoveries of these perennial plant-infecting viruses. A pertinent issue to be considered is whether woody plant-infecting geminiviruses are ancient relics of the family Geminiviridae that coevolved with their hosts. Alternatively, they may be viruses of herbaceous plants that made a host jump to perennial plants; or they may be viruses of wild relatives of woody perennials that have evolved to infect commercial cultivars. Intensive surveys that include sampling of wild relatives and weed species around the vicinities of the infected blocks of orchards and vineyards would help gain some insights into these questions. As more geminiviruses are discovered from woody perennials, thanks to the versatility and sensitivity of the HTS and the RCA technology, as well the culture-independent nature of both technologies, the availability of more sequences would enable a better resolution of the phylogeny and evolutionary history of this family of agriculturally relevant viruses.

The discovery of GGVA by HTS further strengthens the argument for the incorporation of this technology into the grapevine indexing program for the optimal detection of viral pathogens of potential agronomic significance (Al Rwahnih et al. 2015). With the symptomology of GGVA still unclear, its presence would be undetectable by standard biological indexing which relies on symptoms induced by the virus in selected indicator host plants. GGVA would have also escaped detection in standard RT-qPCR assays since these require a prior knowledge of the viral pathogen for the selection and design of virus-specific oligonucleotides. Not surprisingly, all but one (JaMV) (Polston et al. 2014) of the aforementioned woody plant-infecting geminiviruses were discovered via HTS. We hypothesize that more viruses, including those with circular ssDNA genomes, will be discovered and characterized from grapevines especially as the use of HTS technology becomes more routine.

Defective DNAs that are often half the size of the viral genomic components have been reported for several geminiviruses infecting different herbaceous host plants (Patil and Dasgupta 2006 and references therein). To the best of our knowledge, none have been reported for any of the woody host plant-infecting geminiviruses. Therefore, another significant outcome of this study is the discovery of GGVA D-DNA - a natural defective DNA molecule associated with GGVA in cultivar Nagano Purple. We simply refer to this subviral circular ssDNA molecule at this time as defective DNA (DDNA) due to a lack of evidence so far to suggest that it interferes with the replication of the viral genomic DNA molecule as reported for similar geminiviral defective DNA molecules (Ndunguru et al. 2006; Paximadis and Rey 2001). The genome of GGVA D-DNA is roughly half the size of the GGVA genomic component (Fig. 3A and B). GGVA D-DNA was found to occur naturally in a GGVAinfected grapevine and its molecular analysis revealed that it arose due to deletions in the replication associated proteins of the virus (Fig. 3A and B). Unlike some defective DNAs that contain sequences of the helper virus in addition to unrelated sequences such as those associated with Ageratum yellow vein virus (AYVV) (Stanley et al. 1997) and Turnip crinkle virus (Simon and Howell 1986), no nonviral sequence was found on GGVA D-DNA. The sequence analysis confirmed the presence of the complete IR, V1, and V2 genes and partial N-terminal $\mathrm{C} 1$ protein sequences (Fig. 3B and C), suggesting that GGVA D-DNA could be transreplicated by the rep protein of the viral genomic DNA. While there is presently no direct evidence to support the encapsidation of GGVA D-DNA, the conformity of its size, intactness of its V1 ORF and the conservation of potential encapsidation signals such as the stem-loop region (Qin et al. 1998) provide support for the possibility that this subviral DNA molecule may form virions and could be potentially transmitted by a yet-to-be-determined vector species. Furthermore, GGVA D-DNA could possibly exist between the nucleus and the cytosol since it retained the CP-encoded importin $\alpha$-dependent NLS
(Fontes et al. 2004; Rojas et al. 2001). Further studies are needed to dissect the functions of the limited genes encoded by GGVA D-DNA and to determine if this subviral DNA molecule is capable of forming virions.

There is a considerable gap in knowledge regarding the biology of GGVA and its D-DNA molecule at this time. To begin with, the viral genomic and subviral DNA molecules were found associated with a chlorotic ringspot symptom in vines of $V$. vinifera cultivar NP and in mixtures with other viruses (Fig. 1A; Table 2) and the chlorotic ringspot symptom was reproduced on the standard grapevine virus indicator cultivar $\mathrm{Cf}$ in graft-transmission assays (Fig. 1C). However, no apparent foliar symptoms were associated with GGVA when it was present (without GGVA D-DNA) in cv. BB vines. Therefore, the absence of GGVA D-DNA in cultivar BB vines relative to vines of cv. NP makes it plausible to suggest a link between the ringspot chlorotic symptoms and presence of the defective DNA molecule. However, other factors such as cultivar differences, synergism among co-occurring viruses and viroids, etc. could also have contributed to the observed differences in symptomology between NP and BB. Therefore, additional studies are needed to better understand the etiology of the disease symptoms observed in NP and to decipher the pathological effect of GGVA with or without GGVA D-DNA. Further studies are also required to determine the effect of coinfection of GGVA and GGVA D-DNA on the replication of the viral genomic DNA molecule. The availability of infectious clones for GGVA and GGVA D-DNA would help to dissect the compatible interactions among GGVA D-DNA products, the helper virus, and the grapevine host components. Furthermore, the very limited similarities and phylogenetic relatedness of $\mathrm{CP}$ amino acid sequences of GGVA with corresponding sequences of geminiviruses with known vectors (Fig. 5A) makes it impossible at this stage to speculate on a possible insect vector for the virus. Extensive field surveys and periodic monitoring of confirmed infected vineyard blocks could reveal spatial patterns to help determine the nature of a possible vector under field conditions thus helping to narrow down candidates to be included in vector transmission assays.

Limited surveys conducted in the National Clonal Germplasm Repository, the Davis Grapevine Virus Collection, the FPS Introduction Pipeline, and commercial vineyards indicated that although the field incidence of GGVA is low, the virus was detected in multiple grapevine cultivars introduced from six different countries across three continents (Table 5). The identified GGVApositive vines were propagated from introduced grapevine canes thus suggesting that the virus was introduced via cuttings that originated from infected vines from the different country sources. It is therefore likely that GGVA may have a greater global widespread and that it could have been possibly moved across international boundaries undetected due to its novel nature and a lack of consistent symptomology.

A step toward gaining a better understanding of the aforementioned gaps in the knowledge of GGVA and GGVA D-DNA biological properties is the development of diagnostic assays for the routine detection of both molecules and their prevalence in epidemiological studies. The conventional and qPCR assays (Table 1; Fig. 2) developed in this study will prove valuable in this regard. These assays will be useful in studies to determine the occurrence and prevalence of GGVA and GGVA D-DNA in different grapevine-growing regions of the world; the screening of wild grapevines in riparian habitats for possible alternative hosts of the virus; and the screening of insect species sampled from infected vineyards for potential vectors of the virus.

\section{ACKNOWLEDGMENTS}

This project was supported by the American Vineyard Foundation and the Specialty Crop Block Grant Program at the U.S. Department of Agriculture (USDA) through Grant 14-SCBGP-CA-0006. Its contents are solely the responsibility of the authors and do not necessarily represent the 
official views of the USDA. Many thanks to S. Daubert and K. Farrar for critical reading of the manuscript, L. Gregg from the Texas A\&M AgriLife Research for her technical assistance, and B. Prins from the USDA NCGR for his help in providing a list of $V$. vinifera cultivars and the map of the vineyards.

\section{LITERATURE CITED}

Al Rwahnih, M., Dave, A., Anderson, M., Uyemoto, J. K., and Sudarshana, M. R. 2012a. Association of a circular DNA virus in grapevines affected by red blotch disease in California. In: Proc. 17th Congr. Int. Counc. Study of Virus and Virus-Like Diseases of the Grapevine (ICVG), Davis, CA.

Al Rwahnih, M., Osman, F., Sudarshana, M., Uyemoto, J., Minafra, A., Saldarelli, P., Martelli, G., and Rowhani, A. 2012b. Detection of Grapevine leafroll-associated virus 7 using real time qRT-PCR and conventional RTPCR. J. Virol. Methods 179:383-389.

Al Rwahnih, M., Ashita, D., Anderson, M., Rowhani, A., Uyemoto, J. K., and Sudarshana, M. R. 2013. Association of a DNA virus with grapevines affected by red blotch disease in California. Phytopathology 103:1069-1076.

Al Rwahnih, M., Daubert, S., Golino, D., Islas, C., and Rowhani, A. 2015. Comparison of next generation sequencing vs. biological indexing for the optimal detection of viral pathogens in grapevine. Phytopathology 105: 758-763.

Al Rwahnih, M., Alabi, O. J., Westrick, N. M., Golino, D., and Rowhani, A. 2016. Near-complete genome sequence of grapevine fabavirus, a novel putative member of the genus Fabavirus. Genome Announc. 4:e0703-16.

Alabi, O. J., Casassa, L. F., Gutha, L. R., Larsen, R. C., Henick-Kling, T., Harbertson, J. F., and Naidu, R. A. 2016a. Impacts of grapevine leafroll disease on fruit yield and grape and wine chemistry in a wine grape (Vitis vinifera L.) cultivar. PLoS One 11:e0149666.

Alabi, O. J., Villegas, C., Gregg, L., and Murray, K. D. 2016b. Complete nucleotide sequences of a new bipartite begomovirus from Malvastrum sp. plants with bright yellow mosaic symptoms in South Texas. Arch. Virol. 161:1729-1733.

Altschul, S. F., Gish, W., Miller, W., Myers, E. W., and Lipman, D. J. 1990. Basic local alignment search tool. J. Mol. Biol. 215:403-410.

Bottcher, B., Unseld, S., Ceulemans, H., Russell, R. B., and Jeske, H. 2004. Geminate structures of African cassava mosaic virus. J. Virol. 78:67586765.

Brameier, M., Krings, A., and MacCallum, R. M. 2007. NucPred-predicting nuclear localization of proteins. Bioinformatics 23:1159-1160.

Briddon, R. W. 2015. Geminiviridae. In: eLS. John Wiley \& Sons Ltd., Chichester.

Briddon, R. W., Bull, S. E., Mansoor, S., Amin, I., and Markham, P. G. 2002. Universal primers for the PCR-mediated amplification of DNA $\beta$. Mol. Biotechnol. 20:315-318.

Briddon, R. W., Bull, S. E., Amin, I., Idris, A. M., Mansoor, S., Bedford, I. D., Dhawan, P., Rishi, N., Siwatch, S. S., Abdel-Salam, A. M., Brown, J. K., Zafar, Y., and Markham, P. G. 2003. Diversity of DNA $\beta$, a satellite molecule associated with some monopartite begomoviruses. Virology 312: 106-121.

Brown, J. K., Fauquet, C. M., Briddon, R. W., Zerbini, F. M., Moriones, E., and Navas-Castillo, J. 2012. Family Geminiviridae. Pages 351-373 in: Virus Taxonomy. Ninth Report of the International Committee on Taxonomy of Viruses. A. M. Q. King, M. J. Adams, E. B. Carstens, and E. J. Lefkowitz, eds. Elsevier Academic Press, London.

Bustin, S. A., Benes, V., Garson, J. A., Hellemans, J., Huggett, J., Kubista, M., Mueller, R., Nolan, T., Pfaffl, M. W., Shipley, G. L., Vandesompele, J., and Wittwer, C. T. 2009. The MIQE guidelines: Minimum information for publication of quantitative real-time PCR experiments. Clin. Chem. 55: 611-622.

Casado, C. G., Javier Ortiz, G., Padron, E., Bean, S. J., McKenna, R., Agbandje-McKenna, M., and Boulton, M. I. 2004. Isolation and characterization of subgenomic DNAs encapsidated in "single" $\mathrm{T}=1$ isometric particles of Maize streak virus. Virology 323:164-171.

Czosnek, H., Ber, R., Navot, N., Antigus, Y., Cohen, S., and Zamirm, D. 1989. Tomato yellow leaf curl virus DNA forms in the viral capsid, in infected plants and in the insect vectors. J. Phytopathol. 125:47-54.

Finn, R. D., Miller, B. L., Clements, J., and Bateman, A. 2014. iPfam: A database of protein family and domain interactions found in the Protein Data Bank. Nucleic Acids Res. 42:D364-D373.

Fontes, E. P. B., Santos, A. A., Luz, D. F., Waclawovsky, A. J., and Chory, J. 2004. The geminivirus nuclear shuttle protein is a virulence factor that suppresses transmembrane receptor kinase activity. Genes Dev. 18: 2545-2556.

Frischmuth, T., Ringel, M., and Kocher, C. 2001. The size of encapsidated single-stranded DNA determines the multiplicity of African cassava mosaic virus particles. J. Gen. Virol. 82:673-676.
Inoue-Nagata, A. K., Albuquerque, L. C., Rocha, W. B., and Nagata, T. 2004. A simple method for cloning the complete begomovirus genome using the bacteriophage phi29 DNA polymerase. J. Virol. Methods 116:209-211.

Klaassen, V. A., Sim, S. T., Dangl, G. S., Osman, F., Al Rwahnih, M., Rowhani, A., and Golino, D. A. 2011. Vitis californica and Vitis californica $\times$ Vitis vinifera hybrids are hosts for Grapevine leafroll-associated virus-2 and -3 , and Grapevine vitivirus A and B. Plant Dis. 95:657-665.

Krenz, B., Thompson, J. R., Fuchs, M., and Perry, K. L. 2012. Complete genome sequence of a new circular DNA virus from grapevine. J. Virol. 86: 7715.

Krenz, B., Thompson, J. R., McLane, H., Fuchs, M., and Perry, K. L. 2014. Grapevine red blotch-associated virus is widespread in the United States. Phytopathology 104:1232-1240.

Liang, P., Navarro, B., Zhang, Z., Wang, H., Lu, M., Xiao, H., Wu, Q., Zhou, X., Di Serio, F., and Li, S. 2015. Identification and characterization of a novel geminivirus with monopartite genome infecting apple trees. J. Gen. Virol. 96:2411-2420.

Liu, Y., Robinson, D. J., and Harrison, B. D. 1998. Defective forms of cotton leaf curl virus DNA-A that have different combinations of sequence deletion, duplication, inversion and rearrangement. J. Gen. Virol. 79: 1501-1508.

Loconsole, G., Saldarelli, P., Doddapaneni, H., Savino, V., Martelli, G. P., and Saponari, M. 2012. Identification of a single-stranded DNA virus associated with citrus chlorotic dwarf disease, a new member in the family Geminiviridae. Virology 432:162-172.

Ma, Y., Navarro, B., Zhang, Z., Lu, M., Zhou, X., Chi, S., Di Serio, F., and Li, S. 2015. Identification and molecular characterization of a novel monopartite geminivirus associated with mulberry mosaic dwarf disease. J. Gen. Virol. 96:2421-2434.

Maliogka, V. I., Martelli, G. P., Fuchs, M., and Katis, N. I. 2015a. Control of viruses infecting grapevine. Pages 175-227 in: Advances in Virus Research. G. Loebenstein and N. I. Katis, eds. Vol. 91. Academic Press, Burlington.

Maliogka, V. I., Olmos, A., Pappi, P. G., Lotos, L., Efthimiou, K., Grammatikaki, G., Candresse, T., Katis, N. I., and Avgelis, A. D. 2015b. A novel grapevine badnavirus is associated with the Roditis leaf discoloration disease. Virus Res. 203:47-55.

Martelli, G. P. 2014. Directory of virus and virus-like diseases of the grapevine and their agents. J. Plant Pathol. 96:1-136.

Mulenga, R. M., Legg, J. P., Ndunguru, J., Chikoti, P. C., Miano, D. W., Mutitu, W. E., and Alabi, O. J. 2016. Survey, molecular detection, and characterization of geminiviruses associated with cassava mosaic disease in Zambia. Plant Dis. 100:1379-1387.

Nash, T. E., Dallas, M. B., Reyes, M. I., Buhrman, G. K., Ascencio-Ibanez, J. T., and Hanley-Bowdoin, L. 2011. Functional analysis of a novel motif conserved across geminivirus Rep proteins. J. Virol. 85:1182-1192.

Ndunguru, J., Legg, J. P., Fofana, I. B. F., Aveling, T. A. S., Thompson, G., and Fauquet, C. M. 2006. Identification of a defective molecule derived from DNA-A of the bipartite begomovirus of East African cassava mosaic virus. Plant Pathol. 55:2-10.

Osman, F., Leutenegger, C., Golino, D. A., and Rowhani, A. 2008. Comparison of low-density arrays, RT-PCR and real-time TaqMan RTPCR in detection of grapevine viruses. J. Virol. Methods 149:292-299.

Patil, B. L., and Dasgupta, I. 2006. Defective interfering DNAs of plant viruses. Crit. Rev. Plant Sci. 25:47-64.

Paximadis, M., and Rey, M. E. C. 2001. Genome organization of Tobacco leaf curl Zimbabwe virus, a new, distinct monopartite begomovirus associated with subgenomic defective DNA molecules. J. Gen. Virol. 82:3091-3097.

Polston, J. E., Londono, M. A., and Capobianco, H. 2014. The complete genome sequence of New World Jatropha mosaic virus. Arch. Virol. 159: 3131-3136.

Poojari, S., Alabi, O. J., Fofanov, V. Y., and Naidu, R. A. 2013. A leafhoppertransmissible DNA virus with novel evolutionary lineage in the family Geminiviridae implicated in grapevine red leaf disease by next-generation sequencing. PLoS One 8:e64194.

Qin, S., Ward, B. M., and Lazarowitz, S. G. 1998. The bipartite geminivirus coat protein aids BR1 function in viral movement by affecting the accumulation of viral single-stranded DNA. J. Virol. 72:9247-9256.

Rojas, M. R., Gilbertson, R. L., and Maxwell, D. P. 1993. Use of degenerate primers in the polymerase chain reaction to detect whitefly-transmitted geminiviruses. Plant Dis. 77:340-347.

Rojas, M. R., Jiang, H., Salati, R., Xoconostle-Cazares, B., Sudarshana, M. R., Lucas, W. J., and Gilbertson, R. L. 2001. Functional analysis of proteins involved in movement of the, monopartite begomovirus, tomato yellow leaf curl virus. Virology 291:110-125.

Rowhani, A., Uyemoto, J. K., Golino, D. A., and Martelli, P. G. 2005. Pathogen testing and certification of Vitis and Prunus species. Annu. Rev. Phytopathol. 43:261-278.

Saunders, K., and Stanley, J. 1999. Ananovirus-like DNA component associated with yellow vein disease of Ageratum conyzoides: Evidence for 
interfamilial recombination between plant DNA viruses. Virology 264: 142-152.

Simon, A. E., and Howell, S. H. 1986. The virulent satellite RNA of turnip crinkle virus has a major domain homologous to the $3^{\prime}$ end of the helper virus genome. EMBO J. 5:3423-3428.

Simon, A. E., Roossinck, M. J., and Havelda, Z. 2004. Plant virus satellite and defective interfering RNAs: New paradigms for a new century. Annu. Rev. Phytopathol. 42:415-437.

Stanley, J., Saunders, K., Pinner, M. S., and Wong, S. M. 1997. Novel defective interfering DNAs associated with Ageratum yellow vein geminivirus infection of Ageratum conyzoides. Virology 239:87-96.

Stenger, D. C., Stevenson, M. C., Hormuzdi, S. G., and Bisaro, D. M. 1992. A number of subgenomic DNAs are produced following agroinoculation of plants with beet curly top virus. J. Gen. Virol. 73:237-242.
Sudarshana, M. R., Perry, K. L., and Fuchs, M. F. 2015. Grapevine red blotch-associated virus, an emerging threat to the grapevine industry. Phytopathology 105:1026-1032.

Tamura, K., Stecher, G., Peterson, D., Filipski, A., and Kumar, S. 2013. MEGA6: Molecular evolutionary genetics analysis version 6.0. Mol. Biol. Evol. 30:2725-2729.

Varsani, A., Navas-Castillo, J., Moriones, E., Hernández-Zepeda, C., Idris, A., Brown, J. K., Zerbini, F. M., and Martin, D. P. 2014. Establishment of three new genera in the family Geminiviridae: Becurtovirus, Eragrovirus and Turncurtovirus. Arch. Virol. 159:2193-2203.

Zhang, Y., Singh, K., Kaur, R., and Qiu, W. 2011. Association of a novel DNA virus with the grapevine vein-clearing and vine decline syndrome. Phytopathology 101:1081-1090.

Zhou, X. 2013. Advances in understanding begomovirus satellites. Annu. Rev. Phytopathol. 51:357-81. 